\title{
Hospitality Review
}

Volume 6

Issue 2 Hospitality Review Volume 6/Issue 2

Article 1

$1-1-1988$

\section{Managing Strategic Change}

K. Michael Haywood

University of Guelph, null@uoguelph.ca

Follow this and additional works at: https:// digitalcommons.fiu.edu/hospitalityreview

Part of the Finance Commons, and the Food and Beverage Management Commons

\section{Recommended Citation}

Haywood, K. Michael (1988) "Managing Strategic Change," Hospitality Review: Vol. 6 : Iss. 2 , Article 1.

Available at: https://digitalcommons.fiu.edu/hospitalityreview/vol6/iss2/1

This work is brought to you for free and open access by FIU Digital Commons. It has been accepted for inclusion in Hospitality Review by an authorized administrator of FIU Digital Commons. For more information, please contact dcc@fiu.edu. 


\title{
Managing Strategic Change
}

\begin{abstract}
The essay - Managing Strategic Change - by K. Michael Haywood, Associate Professor, School of Hotel and Food Administration, University of Guelph, is initially characterized by Haywood as: "The ability to manage strategic change is critical for hospitality industry executives today. Executives must be capable of creating a vision of the future and implementing its direction. The author gives avenues for that management process."

"The effective management of strategic change is the major challenge confronting hospitality executives," says Associate Professor Haywood. "Responding to a rapidly changing business environment and constantly evolving competitive threats and opportunities requires executives who can anticipate and plan for change.”
\end{abstract}

According to Professor Haywood, the management of strategic change is a future imperative for hospitality executives. Implementing those changes will be even more difficult. "Survival and growth for many hospitality firms during the next decade will depend on the development of new strategic visions which can provide significant competitive advantages," he says. "Strategies for managing costs and technology will be central to this task," Haywood expands the thought.

Haywood suggests two primary types of change hospitality executives should be aware of. First, is change that is anticipated, anticipatory change. Second, is the other more crucial type of change, strategic change in the face of crisis, or simply stated, reactive change. Professor Haywood describes the distinction between the two.

In describing the approach that should be implemented in responding to an anticipatory change, Haywood says, "If time permits, and change is to be introduced gradually, pilots and trials should be run to assess the impact of the new strategy on the organization. These trials are used to create pockets of commitment throughout the corporation, build comfort levels with the new approach, and neutralize or win over potential opposition."

There are the obvious advantages to using an approach like the one described above, but there are disadvantages as well. Haywood discusses both.

In addressing reactive change, Haywood offers that the process is a more - time is of the essence - condition, and that strong leadership and a firm hand on employee control is imperative. "Personal leadership, toughmindedness, the willingness to ruthlessly abandon the familiar and the past, and the use of informal strategic levers are the hallmarks of sterling executive performance in such periods," he says.

"All these changes involve substantial technical, financial, and human risks," Haywood wants you to know. "In order to make them, and still remain competitive, hospitality and travel-related corporations require executives capable of creating a vision of the future, able to sell that vision to their employees, and toughminded enough to implement strategies to make the vision a reality."

Keywords

K. Michael Haywood, Managing Strategic Change, Reactive, Anticipatory 


\title{
Managing Strategic Change
}

\author{
by \\ K. Michael Haywood \\ Associate Professor \\ School of Hotel and Food Administration \\ University of Guelph
}

\begin{abstract}
The ability to manage strategic change is critical for hospitality industry executives today. Executives must be capable of creating a vision of the future and implementing its direction. The author gives avenues for that management process.
\end{abstract}

The management of strategic change will be a vital task for hospitality executives in the years ahead. Formulating new strategies to cope with change is one thing, but implementing them is more difficult.

There are many changes now taking place in the domestic and international environments. Executives must comprehend the tangle of complex political/economic policies, new competitive forces, and innovative technologies at work. For example, deregulation is resulting in a restructuring of the airline industry. Blurring of markets in the lodging sector is shaping the strategies of hotels, motels, and resort companies. Now competitors from Europe and the Far East are intensifying the competitive battle, and new information technologies are revolutionizing front and back office operations. In response to these challenges, a variety of approaches to strategic change are possible. ${ }^{1}$ These take executives into new and unfamiliar domains:

Companies that have grown by developing an innovative family of concepts, such as Grand Metropolitan, one of Britain's largest and most diversified companies, and, more recently, companies like Marriott and Holiday Inn, are having to become more cost-effective or move into new market niches as their original concepts/properties mature. Single concept companies, such as Four Seasons Hotels and many of the major food service corporations, are being forced either to adapt strategies aimed at capturing more added value, or to diversify into new, and possibly unrelated, businesses or both.

All these changes involve substantial technical, financial, and human risks. In order to make them, and still remain competitive, hospitality and travel-related corporations require executives capable of creating a vision of the future, able to sell that vision to their employees, and tough-minded enough to implement strategies to make the vision a reality. 


\section{Vision Is Not Enough}

Bringing about strategic change requires that new objectives and a new direction be implemented. Senior executives, with or without the aid of outside consultants and lower-level employees, can put together new strategies for the corporation and its major functions. The fashionable term for this process is "visioning," and many chief executive officers now have visions of what they want their corporation to be in five or 10 years.

Implementing the vision is far more difficult. Many employees are becoming cynical and frustrated with the contrast between their chief executive's rosy statements about the future and the reality in which most of them find themselves. The president of one lodging company formulated and broadly disseminated his vision for the firm for the year 2000. To his employees, wrapped up in the challenges of staying marginally profitable and keeping their jobs, his dreams caused confusion and cynicism throughout the corporation. Not only was there no strategic road map of how to get there, but his immediate subordinates lacked the commitment.

In contrast, when Juergen Bartels took over as president of Carlson Hospitality Group in 1983, he had a vision; he saw Radisson among the top 10 chains in the United States and among the top 15 in the world within $\mathbf{2 4}$ months. In his first year, Bartels communicated his desire to win big, along with his desire to be number one in quality in each market and segment they served. He saw size and quality together making victory. This could only be accomplished if the Radisson team in every property could accomplish thousands of little victories every day: victories in marketing, victories in cost control, and victories in the loyalty of their customers. He ensured that a strategic plan was in place that detailed every area of operations: franchising, product concept, development, marketing, training technology, purchasing. Nothing was left to chance, not even a plan for implementation.

A vision of the future, shared by all employees, is a strength for any corporation. But new strategies can be threatening for employees who many perceive loss of power, or even loss of employment. Lots of doubts and questions have to be anticipated during the initiation of strategic change. There is also the real danger that senior management will get out of touch with the rest of the corporation and the vision will become a nightmare for all concerned.

\section{Strategic Change Can Be Successfully Initiated}

Strategic change occurs in either crisis/reactive or anticipatory situations. ${ }^{2}$ Crisis or reactive situations are usually brought about by sudden, unforeseen shifts in the business environment, or radical changes in competition. Anticipatory situations occur when executives are able to forecast changes and prepare the organization appropriately.

There are six steps for implementing strategic change: establish clear objectives, capable of demonstrating near-term results; develop an effective change process; ensure top management support and 
continuing involvement in the process; manage subordinate expectations and motivations; remove operational barriers and be prepared to kill "sacred cows;" and reward success.

No matter what precipitates strategic change, the characteristics of the initiation stage are similar, although the length of time spent in this stage may differ: develop a structured process, remove fears of change, anticipate lots of doubts and questions, accept that it could be a time-consuming process, build awareness of the need for change, change attitudes and build commitment, and identify potential problems, issues, and roadblocks. For example, in a crisis situation, awareness of the need for change and subsequent commitment to a new direction may occur within days. When the need for a change in strategy is perceived by only a few people, however, several years may pass before the new strategy is fully implemented. As indicated in Figure 1, initiating strategic change is a continuous activity that comprises three major components:

- substantive actions aimed at clarifying and developing the new strategic direction

- organizational changes aimed at building support and commitment

- executive actions intended to create a climate of acceptance for the new direction.

All three are essential if effective change is to come about.

Figure 1

Initiating Strategic Change

Substantive actions:

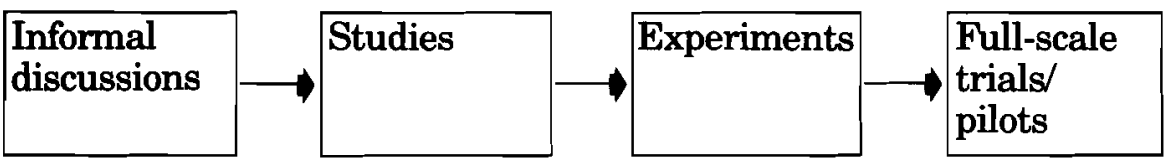

Organizational change:

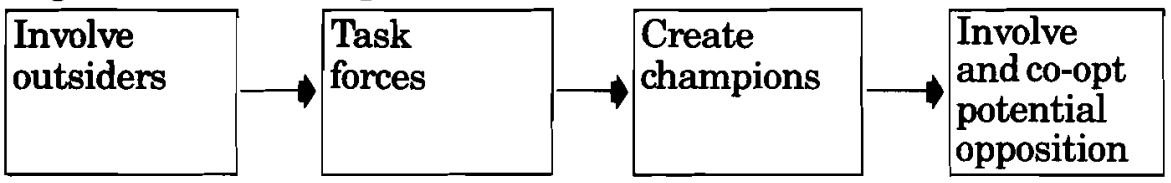

Executive action:

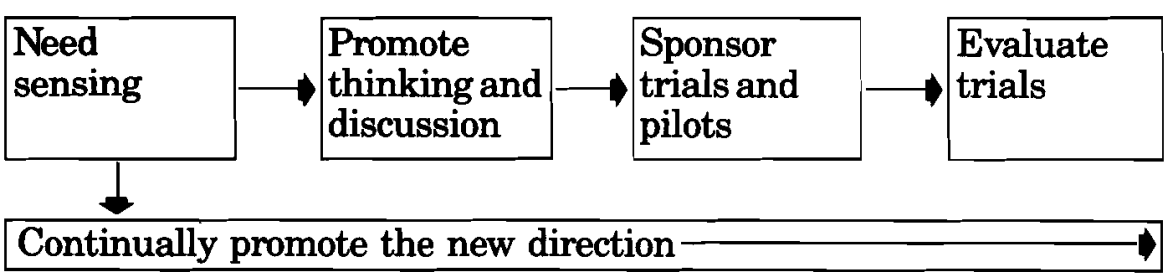


Studies and experiments are necessary to amplify understanding of the need for change, to build awareness, and to legitimize viewpoints. In anticipating change, these activities can be used to clarify and develop the new strategic direction. In crisis or reactive situations, though, modifications are likely to occur during full-scale implementation.

If time permits, and change is to be introduced gradually, pilots and trials should be run to assess the impact of the new strategy on the organization. These trials are used to create pockets of commitment throughout the corporation, build comfort levels with the new approach, and neutralize or win over potential opposition. In its transition to a quality-driven company, Ringer Hut, for example, has utilized a variety of quality enhancement mechanisms such as quality circles, quality control, and total quality management to gain experience and evaluate different approaches. ${ }^{3}$ Trial periods can also be used to assess the level of human and financial resources necessary to implement the strategy on a full scale.

One danger in this approach is that substantial opposition to the new direction may build and cause the trials to fail, throwing the entire strategic thrust into question. This was the case with many pilot employee involvement schemes, particularly in the area of quality circles, during the last decade. Implemented in only part of a company, they often failed to survive the hostility of managers, supervisors, and unions that were not involved.

During a trial period symbolic executive actions, such as executive appointments in line with the new direction, sponsorship of studies and pilots, and periodic reviews, are fundamental to building awareness. Bringing in outsiders who can challenge the prevailing corporate thinking is also valuable. Most importantly, however, senior executives need to spend time promoting and communicating the new direction, although not single-mindedly as to eliminate the incorporation of revisions and modifications as they arise.

\section{Implemention of Strategic Change Differs in Situations}

The way in which strategic change is implemented differs considerably according to the situation. In crisis situations, change has to be managed by direct executive intervention and decision making. When change is anticipatory, executives can use the implementation mechanisms or "levers": corporate objectives and goals, organization structures, communication networks, information systems, policies and procedures, and reward and punishment systems. They create a corporate climate in which employee commitment to the new direction is built, and in which implementation may be made from the bottom up.

Executives who fail at strategic change do so because they do not recognize which approach is appropriate nor the key tasks involved in each. For example, failure in a crisis situation is often owing to senior executives who abdicate responsibility for tough decisions on non-performing employees, resource allocations, or "sacred cows" that are paralyzing the organization. Failure in anticipatory strategic 
change often results from excessive secrecy about the new direction, leading to inertia and lack of commitment throughout the organization.

\section{The Crisis Approach: Top-Down Management}

Strategic change in crisis or reactive situations is a top-down management process in which the willingness to exercise power is central. ${ }^{4}$ Failure on the grounds that subordinates could not agree on a course of action is not an acceptable excuse. Personal leadership, tough-mindedness, the willingness to ruthlessly abandon the familiar and the past, and the use of informal strategic "levers" are the hallmarks of sterling executive performance in such periods.

Pending insolvency or the rapid erosion of markets by competition leaves little time for the initiation steps previously described. In these circumstances, strategic change has to be a process directed from the top down, often in the face of opposition from and disagreement among lower-level executives who have only a partial view of the complete strategic situation and who fear the loss of their own power.

Consensus management is practically impossible under these conditions, yet it is vital that dissension or substantive issues within top management not paralyze the corporation. One major restaurant corporation wasted a year, and lost significant market share, as executives fought over the "correct" strategic response. As an employee later said, "Anything would have been better than the nothing that came out of the executive suite."

Edwin Land, former Polaroid chairman, stated that during such critical periods he would not allow executives to criticize new directions or ideas. Other chief executives ensure commitment to a major new direction in individual interviews with their executives, offering a generous severance package if the subordinate cannot completely support the proposed course of action. A fully committed executive team is the single most important success factor during periods of rapid strategic change.

The commitment of lower-level employees is best gained by direct communication between senior executives and the work force. This is one time when "management by wandering around" really pays off, even though there is a temptation during rapid change for executives to remain at the helm in the corporate office.

An executive who has directed several corporate turnarounds says that his major policy in this period is "communicate; communicate; communicate." Employees who are aware of the challenge facing them, and who understand the need for quick, tough decisions, are generally quick to accept reality and commit themselves to the new direction.

Long planning sessions are unproductive when rapid strategic change is necessary. Instead, having agreed on an overall strategy, successful executives prefer to hold frequent meetings throughout the organization. Progress is reviewed and a limited set of actions is agreed on for the period immediately ahead.

In crisis change there is little time to prepare extensive plans, 
change the organization, or argue alternative courses of action in depth. It is time for boldness in action and willingness to take on additional business risk for strategic advantage. Obstacles to change and "sacred cows" have to be identified and eliminated through direct top management intervention. Some resource misallocations are likely in this period, and follow-up to ensure that the cow is really dead is usually necessary.

Existing strategy implementation mechanisms are also major barriers to rapid change. Organizational structure may be overly hierarchial, lending inflexibility and inertia to decision making. Resource allocation policies and reward systems often promote the status quo and discourage innovation.

In such circumstances executives know that radical surgery is necessary. Levels of management and supervision have to be eliminated, and long-established policies and procedures circumvented or abandoned. For the short term at least, personal and informal procedures are most effective until time can be found to institutionalize new structures and policies that support the changed strategy.

\section{Anticipatory Change: Mobilizing the Organization}

When it is possible to anticipate and plan for change, the executive role becomes one of preparing the organization and creating a climate in which the commitment and involvement of many employees can be the driving force. The sponsoring of champions of the strategy, the use of modified formal strategic "levers," and a willingness to persuade rather than order supplement demonstrated personal commitment as key factors in this type of strategic change.

In well-prepared anticipatory change, it should be possible to carry out many of the initiation activities already described to prepare the organization for full loyalty to the new strategy. Trials and pilots will have identified new strategic thrusts which can now be followed up with major resource allocations. Changes to information systems, organization structure, rewards, and corporate culture can be planned for and implemented in a staged manner.

The major threat to the success of this type of strategic change is resistance, usually passive, emanating from employees in middle management who are unwilling to abandon old approaches or incur personal risks associated with moving in a new direction. Put simply, nothing happens.

Usually the success of initiatives taken by the strategy's champions encourages others to follow. In addition, pressure to change from both above and below influences middle managers, so it is important for executives to mobilize the rank and file. To ensure success, however, executives must be prepared to deal with managers who, having been given a reasonable period for adjustment, demonstrate a total aversion to change.

During anticipatory change, executives may spend as much time in communication sessions listening to the views of employees as in promoting the new direction. Feedback from throughout the organization can provide useful information on how well the new strategy is 
being accepted, as well as ideas for fine tuning. Executive planning and review sessions, held at least quarterly, are important in keeping implementation on track.

Continuing top-management support can be demonstrated in a variety of ways. The most important is ensuring that strategic programs are adequately resourced. Failure to provide sufficient support for strategic initiatives is a major cause of failure and tardy implementation. Executive sponsorships of major strategic thrusts, personal recognition of successful innovators, and occasional intervention to eliminate road-blocks are further tangible ways to provide leadership.

\section{Future Challenge}

Survival and growth for many hospitality firms during the next decade will depend on the development of new strategic visions which can provide significant competitive advantages. Strategies for managing costs and technology will be central to this task. Transforming the corporation will, however, be a major additional responsibility for executives.

The effective management of strategic change is the major challenge confronting hospitality executives. Responding to a rapidlychanging business environment and constantly evolving competitive threats and opportunities requires executives who can anticipate and plan for change. If the process is managed effectively, strategic visions can turn into profitable realities.

\section{References}

'Jeffrey D. Schaffer, "Competitive Strategies in the Lodging Industry," International Journal of Hospitality Management, (1987), pp.33-42.

2Joseph N. Fry and J. Peter Killing, Strategic Analysis and Action, (Scarborough, Ont.: Prentice-Hall, Canada, Ltd., 1986), pp. 257-322.

${ }^{3}$ Christopher W. L. Hart and Gregory D. Casserly, "Quality: A Brand-New, TimeTested Strategy," Cornell H.R.A. Quarterly, (November 1985), pp. 52-63.

"Charles Brewton, "Managing a Crisis: A Model for the Lodging Industry," Cornell H.RA. Quarterly, (November 1987), pp. 10-15. 